\title{
THE STRUCTURE AND PROBLEMS OF TURKISH AGRICULTURE
}

\section{Havva TUNC}

\section{Abstract}

This paper examines the stwoture of Thrish Agriculture and its problems by using statistical data. The artale begin the analysis with explainimg the importance and position of agricultural sectar. Then the outlines of the structure and problems of Turkish Agriculated Sector as well as agricultitat poliches and their impact are analyzed. Before concluding, a brief evaluation of the overview of Thek the agriculatal systen is atsested. By this article, an attempt is made to andyze some of the agriculumal policies that have been applied to the Turkish Agriculture Sector. The article also sagedests way to improve Turkish Agritulure.

Keywords: Thkist Agriculture, Structure of Turkish Agriculture, Rumal Population, Problems of Turkish Agricultural Sector, Turkish Agricultural Poticies.

Oret

Bu falumala Tük Tarmin yapisz ve sortutar, saysal veriler

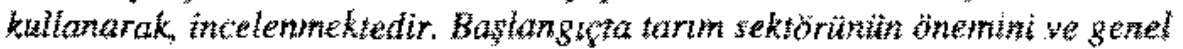
durtumu verildi. Sontra Turk Tarm Sektorimin yasts ve problemleri, uygulatan vetveya tygulanmakta olan tamm politikalart ve onlann

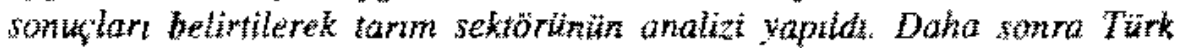
Tarm Setobrïnün genel garäniminün bir degerlendirilmesi yaplat. Tark Tarimmin gelisimi ighn aimmasi gereken ömlemier ve yaplmasi gerekenler belintlerek çalş̧a sonlandüldt.

Anahtar Kelimeler: Tüb tarmt, Tük tarmunt yapusi, Kirsal Nufus, Turk tarm sektörinün sorunlart, Türk tarm politikalart.

"Prnf. Dr, Istanipl University, Department of Econsinics. 


\section{Introduction}

The agricutural sector has great importante for national economy becase of poviding nutritional prodtets for howseholds, taw materials for industrial sector and creating detnond for industral proututs and also is a great soutse af national income.

Turkish agricultural sector constitutes $15 \%$ of the nationat incomat and 35 等 of the total employment and in addition its social importance is as prominent as its conomical importance.

In this study, first we will display the present simuture of the sector and try to detemine its problems. Sccondly, aysticultural policies from eaty Turkish republic to today ard their inplications are analyzed. Finally, the effects of eliminating subventions and interventons in agriculural policies afier the "Stand By Treaty" with IMF in 1999 are investigated.

\section{An Overview of Agrieultural Sector}

\subsection{Importance and Positions of Agricultural Sector}

Agriculture is one of the most "protected" sectors in both developed and underdevaloped countries. These wide protective measures and subvention policies are related to the inherent nature of agriculture: Agrionlture was fo: centuries, and still is, just as wuch a why of life as an economic activity. The olose relationship with nature, the thes with land and the dependence on climate is a hundamental characteriste of faming. On the other hand, as the structure of demand is fat from being flexthe, the fluctuations in production lead to large varations in prices, and hence, in the income of the farmets.

The agricthural sector is the basic source of nutritional materal for consumers. For this reason, govemrnents resont to agriculural stabuntions for both stabilizing farmers' incomes and potecting consuncts.

The alvancement of agriculture is also important for industrivalization. Developed countries have achicved their high tevel of development by increasing atricultural productivity and transferring added vatues in agricultural sector to non-agricultural sectors. At the early stages of industrialization, agriculture was the key sector providing toreign exchange On the other hand, in higbly industrialized countries and in countries at the end stages of industrialization govermments apply protective measures both as a corsequence $\mathrm{f}$ development and also to meet the incressing presclutes 
of the population working in agricultural sector. The protective neasures range from giving subventions and stabilizing product prices, supporting agricultural inputs, back-up buying and storing, to expont and import policies.

In the industrialization process, the ratios of agricultural income to national income and agricultural labor force to total labor force both decrease gradually. For example, in infustrialized countries both of the ratios are below $10 \%$ (see tables 6 and 7 ). This structural property is one of the principal indicators of industralization. The reason underlying this fact is on one hand the bigh rate of increase in the productivity of the land and of the labor, on the other hand the limited demant for agricultural products comparef to total income. As the income increases, the portion of the expenditures on agricutural products decreases. In other terns, agricultural products have low "income elasticity". Therefore, the target of the agriculture should be to provite satisfactory nutrition for the national population and to tse comparative advantages in intemational markets in order to reack satisfactory export levels with relatively low lahor fore. Once this goal is achieved, the protlem of per capita income in agriculture will be solved as the syerate agricultural income will be close to the average national income.

If the share of employment in agriculture in the total employment is decreasing and if the share of ngriculrure in GNP is increasing the agricultural secter will develop. On the other hand if agricultural value added is not tansferred to the industrial sector and also if agricultural developing should not be accompanied with industrialization so neither agricultural development not industrial development wil be successful

\subsection{General Properties of the Agricultural Sector}

Agricularal sector has general distinctive features, which give rise to certain problems even in developed countries. We can summarize these features as follows.

1. Agricultural sector depend highly on natural factors. Even in countries with high technological level, agricuttural sector should have privileges. The sector is protected against bad conditions that the agricultural producers may encounter. 
2. There is a delayed supply reaction to the variations in agricultural demand. In other words, agricultural products have low supply elasticity in the short run. In addition, the agricultural supply is a function of the price of the product in the previous period.

3. Agricultural production is for both the market and self-consumption; that is, it has a dual structure.

4. In agriculture, as opposed to the industrial production, "the law of diminishing productivity" is valid. This discourages the use of addition capital in agriculturc. In other words, the use of capital-intensive technologies in agriculture is limited.

5. The market conditions of agricultural businesses are different. A large number of scattered agricultural firms sell their production in the nearby markets under full competitive circumstances, while they purchase their inputs from "oligopoly" or "monopoly" markets.

In the light of these rcmarks, if there is no "government intervention", producers of agricultural products are vulnerable to exploitation both when purehasing the inputs and when selling their products. They are exposed to full-competitiveness situation when selling their output, measurable to oligopoly circumstances when purchasing their input.

\section{The Structure and Problems of the Turkish Agricultural Sector}

Looking at the ratio of the agricultural income in total Gross National Product (GNP), the ratio of agricultural export in total trade, the ratio of the rural population, and the ratio of agricultural labor force in total labor force, one can see that Turkey has more "agricultural" and "rural" appearance compared to countries with a similar national income. Thus, it will take relatively more time for Turkey to reach the stage of an industrial and urban society with respect to countries in the same income group.

\subsection{The Structure and Problems of the Rural Population}

The census results show that Turkish population has trend of increase. The distribution of the population between rural and urban areas differs with a trend of decrease in rural population and a trend of increase in urban population. The total population, the rural/urban population distributions are given in Table 1 and it can be seen that although there is a decrease trend, the ratio of rural population is still high. For example, the ratio of the rural 
population tn total population is $68 \%$ in $1960,56 \%$ in 1980 , and 35 F in 1997.

Although the ratio of the agricultural labor force to total labor force is

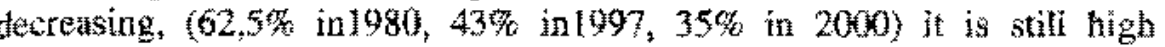
compared to developed countes $(5,8 \%$ for $\mathrm{EC}$ and 8.1 w 2000) (TOB), 1990).

Comparing with other sectors, it can be seen from Table 4 that size of the agricuiture places it at an important position in Turkish economy. The $35 \%$ share of agriculturat employment in total population is much higher than the thet sectors while the ratio of 13.4 䖽 of agricultural income to grosa national puaduct is extremely low compared to other sectars, In other words; the agricultural production is quite anproductive because of over popalation his sector, insufficient technology and traditional production methods. lack of awareness of market conditions, and lack of conscious of producing for the market. It should also be remembered that land is constant as an input

In addition, the ratio of the ageicultural income in gross national income

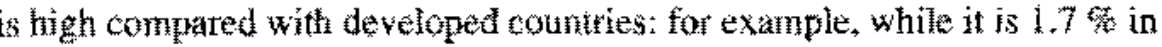
USA axtd $1.9 \%$ in EC, 13.4\% in Turkey (see tables 5 6 ).

After 1980 s, protective and supportive policies have been abandoned and the farmers have found themmelve in a full competitive manket before getting ready for it. As a testut, this situation had a controversial effect in achieving the expected developruent in agriculture.

\subsection{Agricultural Production and Gross National Product}

In developed conomies such as USA and EC, the ratio of the agricultural income in total GNP is as low as $2 \%$. In Turkish economy, this ratio is, $13.4 \%$. The contribution of agriculture to external trade is $14 \%$ in USA while it is $7 \%$ in Turkey (see Tables 5 and 7 ).

This shows that the contribution of agrieulture to external trade is low while its contribution to GNP is high. This is due to the following facts: Fisstly, rural peputation is intensive; secondly, the grotective and supportive policies are minimized; and thirdly the agriculurad production is left face to face to competizye market conditions. In agricuitural sector, if the national markat comes face to face to international competition, the sector will, in general, be hamed. In addition, nutural disasters would aggravate the shtuation as it happened in Turkey. 
In developed colntries, the contribution of the agriculture to CNP is low while its contribution to trade is high. They are applying protectite and supportive policies to an alreaty low klenxity population in agricultural sector. For example, in EC, about 45 of of the EC butiget is allocated to the

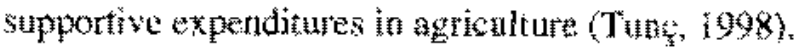

\subsection{Agricultural Production and Trade}

It can be seen that the relative imporance of agriculture in Turkish economy decrease with time. The state of agriculture in total exports

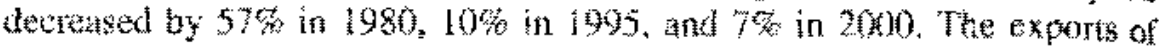
agriculntal products decreases while their imponts increases. The share of agticultural produes in toulal exports in developed countries is, for example $14 \%$ in USA and $89 \%$ in EC whlle it is 7\% in Turkey (Ttmc 1998 ).

The teduction of the share of Turkish agriceltural products an the woth trade has been a consequence of liberal policies implenented after 1980 's.

\subsection{The Denand and Supply of Agricultural Inputs}

\subsubsection{Agricultural Inputs}

The development of Turkish Agticulture provides a considerable ampunt of inputs to mon"agricultural sectors As of 1963 . 28 of of intermediate products have been produced by the agriculuturat sector (Dura, 1987). This figute was $27 \%$ in $1968,26 \%$ in $1973,19 \%$ in 1979 and 13 ty in 1985 . Despite this decrease in time, these rativs are still high conpared to industral countries. For example in USA and UK, the agricultoral inplits constitute only 1 co the internediate gonts. The petcentage of agricultural inputs in internediate goods is an indieator of the degree of dependency of the industry on agriculture. In other words, Turkish industy is fighly dependent on agrioultu* compared with developed eountries.

Agriculutal development infitenes the demand for industrial products in two ways. The first one is the increase af the demand on goods directly used in acricultural production, such as chemical fertilizers, ingricultural drug, equipments etc. The second onc is the incretse in the ineome of the producers in agticalturat sector which increases their demand on consumption and investment goods. 


\subsubsection{The Use of Modern Inputs and Productivity in Agriculture}

The labor force and land are the basic inputs in agricultural production. Although the ratio of the agricultural labor force is gradually decreasing, it is still high compared with the standards of industrial countries. After 1960s as the available land has reached its natural boundaries, farmers started to use mechanization and high technologic inputs at an increasing rate. The use of agricultural machines and equipment and tractors have increased till 1980 and decreased afterwards. This decrease is due to the liberal policies adopted with "January 24 Decisions in 1980" with which the prices of agricultural equipment and credit interest rates are raised to market levels (Tunç, 1990). As a result, the cost of getting credit has increased, the degree of mechanization of inputs slowed down, and the productivity of this already unproductive sector has further decreased. As another implication of the liberal policies, the agricultural market was opened to agricultural imports; high-cost local agricultural products were forced to an unfair competition with low-cost foreign goods.

In a similar way, the widespread use of modem inputs such as chemical fertilizers, irrigation, agricultural drugs and high quality seeds after $1960 \mathrm{~s}$ lead to an increase in productivity. However, after 1980s, because of the liberal policies, as the farmers could not afford these inputs, they stopped using them and productivity decreased.

\section{Turkish Agricultural Policies and Their Impacts}

\subsection{Agricultural Policies and Their Impacts Till 1990s}

In Turkish agricultural sector, protective and supporting policies had been adopted till 1980s. By this time a certain development trend had been caught because of subventions in oil prices, agricultural equipment bought with negative interest rates, the increase in the variety of support-buying and the encouragement of modern inputs. After $1980 \mathrm{~s}$, the use of high-tech inputs were disrupted because of the increase in interest rates, market priced fuel-oil and agricultural equipment resulting from liberal policies. In addition, as the Central Bank adopted higher interest rates for agricultural credits, the use of agricultural credits decreased. The amount, variety and extent of support buying on product basis decreased, resulting in a decrease of the governmental contribution to the market as a buyer. Supporting agriculture with high interest rate credit has been abolishment. Product base prices were lowered. Subventions for inputs were decreased. The adopted 
price policy was not protecting the producers and input prices were high than produck market prices.

Support prices maintatned for a few products and/or group of product a not enough. The subventions taken off from producer are given to 1 traders of agricultural products. For example, the subventions in tobace and nut which was given hitherto to their prodzcers, is given now to tz traders.

The prime systern was started to be used instead of subventions and w: first applied to cotton. But present prime system chncerning a few produc is not sufficient for the sector. In fact hat application of the systen can gis us opportunity of manipulation the amount of production. It means that there is a stortage of some goods, we can increase this goods production 6 vice versa. To explain it considers this example: suppose a farmer produce tobaces and earns in bilition dollars. But we plan to decrease the toback production and increase nut production. If the farmer produces nuts instea of tobaceo, he would earn 7 billion dollars hence he would lose 3 billio. dollars. His losing of 3 billion dollars is paik to the farmer directly by th government in the prime system. But these policies do not give expecte results. It means that it has been increasing neither antount of production nor incoming of farmers.

\subsection{Agricultural Policies and Their Impact after 1990}

The objective of Turkish Agnicultural setor and procedures to achiev them are determined within the "Agriculture Section" of the "IMF Stand-b; Agrement" of 1999 . This agreement strtes that direct income suppor policies will be applied but the base and ceilstige price policies will bo abolished. The govemment will involved in buying process, the trade 0 agricultural goods will be done under market conditions and Nationalize Corporations (N) and State Economic Enterprise (SEE) will be privatized.

NI and SEE which are cornerstones of Turkish agricultural system at protecting the agricultural sector againstit unfair competition, The privatization means the unprotected exposure of the famers to marke conditions, and the extermination of the agrieuluarat sector in the long tem According to the "amendments to the stand by agrement" with IMF afte the financiat crisis of November 2000 and Februtry 2001 Tunc, 2001), an 21st item of the "intend letter" send to IMF on May 3, 2001, it is clearly stated that legislative process for the abolition of the monopoly on sugar an 
tobacco production will be completed and "sugar law" will be passed. In addition the tobaces sector will be liberalized that supporting buying will be abolished and tobacco law will be passed.

In the $32^{\text {to }}$ ttem of the intend letter, it is also stated that sugar quotations will be decreased and support buyouts for grain will be decreased. In agreenent with the direct income support policy, the support prices will not be higher than the expected inflation rate.

The determinations of suppor prices have always been problenatic. With a new legislation, the governmental of support prices especially in grain, sugas and tobacco will be ended in becember 2002. Furthermore, till that time, the support prices are expected to be deternined in such a way to catch the market prices by 2002 (TCMB, 2001). It is planned to diminish the subventions and support prices gradually until its annulations by fall 2002 (DPT, 2001). As a result, the producers will have to sell at a price below their production cost and will be forced to leave the sector. On the other hand, prices above the word market prices are not desired, became they lead to unproductivity and to the regression of the sector. The problem is not the determination of the price, but exposure of the producers in the competitive makket without structural improvement measurs.

We can say that the "Turkish Agriculural Policies" being applied today and that will be applixd in future are a bunch of measures far away from protection and support but to the contrary are leaving out the sector to the internal dyramics of the market. As stated, "Direct Income Suppor" policy will be implemented in this way support prices will be parallel to the world market prices and hence, real prices will be pulled down. There will be limits to the subventions in inputs and credits, and these will be ended in time:

\section{The Evaluation of the Agricultural Sector}

The liberal policies in Turkish agricultural sector started in 1980 and culminated with stand by agreement with IMF in 1999 and the financial crisis of November 2000. In Turkish agricultural sector which constitutes $35 \%$ of the labor force, $14 \%$ of the GDP, $7 \%$ of total exports and 5 w of the total imports, the passage from supportive to competitive policies will result in the loss of any chance of catching a development trend. However a restrteturing of the protection and support measures in order to increase productivity would be more desirable than their complete abolition. The 
development of the Turkish agricultural sector has been handicapped by th delay in passing from household economy to market economy, the lo income level and the population intensity. In the present situation, as th sector has not yet reached a development trend, producers exposed to th competitive market, will either leave the sector or will be under the contr of trade sector.

In developed OECD countries where the agnicultural sector has a sha of $1-2 \%$ in national incomc, $5 \%$ in total workforce, the farmers get $40 \%$, their income from government support, while this figure is $31 \%$ in Turke (Boratav, 2000). In these developed countrics consumers pay $31 \%$ mo because of agricultural supports while in Turkey they pay only 14\% more the support price (Boratav, 2000). In short, in Turkey; agricultural support lower than OECD average. The US dollar amount of subventions per farm is 15 times more in OECD than in Turkey (Boratav, 2000).

In both developed and developing countries, there is a need fo supportive policies in agricultural sector because of its structural properties

The possible impacts of ending supportive polices on Turkis agricultural sector can be summarized as follows.

i) There will be a decrease in agricultural production

ii) Agricultural exports will decrease

iii) Agricultural imports will increase; in addition to a loss of incom expenses will increase

iv) The unemployment will increase in rural areas.

v) The immigration to urban areas will increase.

In order to achieve any development in Turkish agricultural secto "supportive and protective" policies should be adopted. The amounts a processes of production should bc determined for each group of good Some goods that have been producing unproductively should be ende There should be no farming in unproductive land; domestic prices should close to world prices but the difference should be paid to the producers. areas of discontinued production, direct income support should be given the producers and they should undergo educational prograns for getti new skills. New policies for the regulation of overpopulation in agricultu should be implemented. 


\section{Conclusion}

Turkish Agricultural seetor had been the locomotive sector for achievement. It means that the share of agriculure in total exports had been high enough, it provided the inputs necessary for non-agricultural sectors and it also had produced enough food side products for household consumption.

In 1980's, as a result of liberalization policies in agricultural sector, the domestic market came face to ace with products from developing countres. These low" cost products were mote advantageous for the consumer and they started to replace domestic production. $A s$ a result, Turkish farmers lost theit share in the market and their income decreased.

In the framework of the Standwby Agreement, Itberalization or free market policies started to be applied. In addition, the agriculturat sector was also confronted with the financial crisis of 2000-2001, which worsened the situation.

As we look at the agriculural polictes atopted in developing countries. we see that they have applied "conservative poliches" that include support, protection and subvention. For example, both European Communities and USA are applying conservative policies in their agriculural sector.

As a result, we can conclude that, as the agricultumat sector is different from other sectors because of its structural and the external conditions it is faced to, it has to be supported both in developed and developing conntries. The crucial point is the type and amount of support.

Countries in which agricultural sector is not developed, will never reach higher development levels. Therefore tn agricultural sector we haye to apply conservative policies for industralization. The degree of conservative and the determination of the set of produets to the conserved depend on the development level. 
Tables:

\begin{tabular}{|c|c|c|c|c|c|c|}
\hline \multicolumn{7}{|c|}{ TABLE I } \\
\hline \multicolumn{7}{|c|}{ Total Population, Rural and Urban Population Gased on Census Data } \\
\hline & \multicolumn{6}{|c|}{ Yeters } \\
\hline & 1660 & 1970 & 198 & 1965 & 1990 & If \\
\hline $\begin{array}{l}\text { Total } \\
\text { Pofstilaton }\end{array}$ & 27.754 .820 & 35.695 .467 & 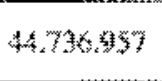 & 雚.664.458 & $56,473,055$ & \\
\hline $\begin{array}{l}\text { Futral } \\
\text { Popolation }\end{array}$ & 8.84 .731 & 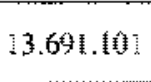 & $19.6,45,00 \%$ & $26,865.75 \%$ & 33.326 .351 & \\
\hline $\begin{array}{l}\text { Shate of } \\
\text { Rural Po. } \\
(\%)\end{array}$ & $3 ! 92$ & 38.45 & 43.91 & 53,09 & 59.01 & 6 \\
\hline $\begin{array}{l}\text { Erbstan } \\
\text { population }\end{array}$ & 18.895 .089 & 21.914 .075 & 25.091 .950 & 23.798 .701 & 23.146 .684 & \\
\hline $\begin{array}{l}\text { Share of } \\
\text { Whtrat } \\
\text { posto }\end{array}$ & 级配 & $6 \pm .55$ & 5. & 4697 & 40.39 & 35 \\
\hline
\end{tabular}

TAMLE 2

\begin{tabular}{|c|c|}
\hline \multicolumn{2}{c}{ TABLE 2} \\
\hline Ratio of Agricultural Employment to Total Employment \\
\hline Years & Share of Agricultural Employment in Total Employme \\
\hline 1970 & 70.2 \\
\hline 1980 & 62.5 \\
\hline 1990 & 46.1 \\
\hline 1999 & 42.8 \\
\hline 2000 & 35.2 \\
\hline
\end{tabular}

Source: DPY, VII.BYKP, Ankara, 2000 .

\begin{tabular}{|c|c|c|c|}
\hline \multicolumn{4}{|c|}{ TABLE 3} \\
\hline \multicolumn{4}{|c|}{ Share of Agrculture in Total Employment ( o } \\
\hline & & Yense & \\
\hline & 1999 & 2000 & 2401 \\
\hline $\begin{array}{l}\text { Active Poptlation } \\
\text { (1000) }\end{array}$ & 23.986 & $2 \mathrm{z}, 100$ & 23.255 \\
\hline Agricititsire $(1900)$ & 9.152 & 7.628 & 7.660 \\
\hline 㴽 & 42.8 & 35.2 & 30.0 \\
\hline
\end{tabular}

Source: DPT, 2001 Ýll Program, Ankara, 2000 . 


\section{TABBLE 4}

\section{Comparing with Other Sectors of Agriculture}

\begin{tabular}{|c|c|c|c|}
\hline & $\begin{array}{c}\text { GNP } \\
\text { (Billion } \$ \text { ) }\end{array}$ & $\begin{array}{l}\text { Employment } \\
\text { (1000 person) }\end{array}$ & $\begin{array}{c}\text { GNP/Employment } \\
\text { (Per capita \$) }\end{array}$ \\
\hline Agriculture & 29.037 & 7.628 & 4.040 \\
\hline Industry & 46.378 & 3.713 & 12.424 \\
\hline Services & 116.038 & 8.330 & 13.930 \\
\hline Construct & 10.519 & 2.329 & 7.915 \\
\hline Totals & 201.972 & 22.100 & 9.815 \\
\hline
\end{tabular}

\begin{tabular}{|c|c|}
\hline \multicolumn{2}{|c|}{ TABLE 5 } \\
\hline \multicolumn{2}{|c|}{ Share of Turkish Agriculture in Gross National Product } \\
\hline Years & GNP/Agriculture (\%) \\
\hline $1923-24$ & 43 \\
\hline 1939 & 40 \\
\hline 1970 & 36 \\
\hline 1980 & 25 \\
\hline 1990 & 16 \\
\hline 1997 & 13.4 \\
\hline Source: DPT, VIII: BYKP, Ankara, 2000, s.39 \\
\hline
\end{tabular}

TABLE 6

\section{Share of Agriculture in Gross National Product in Developed Countries}

\begin{tabular}{|l|c|}
\hline Countries & $\%$ \\
\hline USA & 1.7 \\
\hline EC & 1.9 \\
\hline Japan & 4 \\
\hline \multicolumn{2}{|l|}{ Source: DPT, VIII.BYKP, Ankara, 2000.s.39. } \\
\hline
\end{tabular}

\begin{tabular}{|l|c|c|c|c|}
\hline \multicolumn{5}{|c|}{ TABLE 7 } \\
\hline \multicolumn{5}{|c|}{ Distribution of Agricultural Production } \\
\hline$\%$ & Vegetal & Animal & Sea Food & Tree Products \\
\hline Turkey & 57 & 34 & 2.9 & 5.8 \\
\hline Developed Countries & 30 & 70 & - & - \\
\hline Source: DPT, VIII.BYKP Tarm İstatistikleri, Ankara, 2000. \\
\hline
\end{tabular}




\section{TABLE 8}

\section{Gross National Preduct in Turkish Economy}

\begin{tabular}{|c|c|c|c|c|c|}
\hline & 1999 & 2000 & 2001 & 2102 & 2003 \\
\hline GN" Growth & $-6,1$ & $-6,1$ & -30 & 5,4 & 6,0 \\
\hline $\begin{array}{l}\text { GNP QQuatrilion } \\
\text { TLi }\end{array}$ & 78,3 & 126,0 & 132.4 & $24.5,8$ & $3)_{7} 6$ \\
\hline GNP (Mintion $\$$ & 187,4 & 2019 & $\$ 70,7$ & 188,5 & 203,3 \\
\hline
\end{tabular}

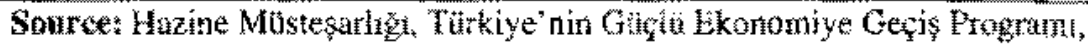

Ankatri, $20901,599 . T .2$

\section{TABLE 9}

\begin{tabular}{|c|c|c|c|c|c|}
\hline \multicolumn{6}{|c|}{ TABLE 9} \\
\hline \multicolumn{6}{|c|}{ Rate of Growth of Sectors in Turkish Economy } \\
\hline & 1999 & 2000 & 2001 & 2402 & 2013 \\
\hline Agriculatase & $-3,0$ & 41 & 1,2 & 5,3 & 1,2 \\
\hline Industry & $-5,0$ & 5,6 & -3.5 & 5,1 & 6,6 \\
\hline Serviet & $-\frac{1}{3}=$ & 8,7 & $-3,7$ & 4,3 & 6,6 \\
\hline GDP & -4.7 & 7.2 & $-1,0$ & 4,7 & 59 \\
\hline GNP & $-6,1$ & 6.1 & $-3,0$ & 5,0 & 60 \\
\hline
\end{tabular}

\begin{tabular}{|c|c|c|c|c|c|}
\hline \multicolumn{6}{|c|}{ TABLI 10 } \\
\hline \multicolumn{6}{|c|}{ The Share of Agriculture in the Total Exports and lreports } \\
\hline & \multicolumn{5}{|c|}{ Years } \\
\hline Trate The & 1980 & 1990 & 1995 & 1999 & $2000^{\circ}$ \\
\hline $\begin{array}{l}\text { Total Exports (billion } \\
\text { dollar) }\end{array}$ & 2.910 & 12.959 & 23.636 & $26 . \overline{588}$ & 10.167 \\
\hline 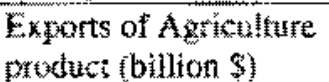 & 1.672 & 2.347 & 2.307 & 2.592 & 789 \\
\hline $\begin{array}{l}\text { Share of agticulture in } \\
\text { total axports (y) }\end{array}$ & 57.46 & 18.11 & 10.66 & 9.75 & 7,07 \\
\hline 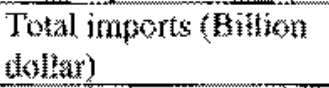 & 7.909 & 22.302 & $35.71 \mathrm{f}^{2}$ & 40.687 & 29.379 \\
\hline 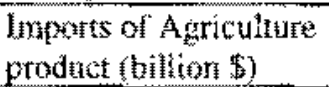 & $\$ 1$ & 1.318 & 2.444 & 1.814 & 1.062 \\
\hline 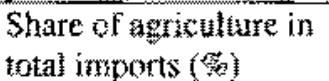 & 0.64 & 5.91 & 6.84 & 4.46 & 5.21 \\
\hline
\end{tabular}




\section{Reforences:}

Archet, $\mathrm{C}$ and Buter $\mathrm{F} .(1992)$. The Europedn Community sivuture and Process, New York: St.Matin's Press.

Boratav, K., (16.02.2000), 'Tanmsal Destekleme: Türkiye'de OECD'de'. Cumhuriyet Gaztesi.

Devlet İtatistik Enstitusii (DIE) (1993), Türkiye Istatistik Yllhğ', Ankara. Devlet Plankama Teşkilat (DPT) (2000 a). 'VIIl. BYKP', Ankara.

Devlet Ptanlama Teskilat (DPT) (2000 b). Tarmsal Politikalar ve Yaptsal Düzenlemeler, Ozel Ihtisas Komisyon: Rapon, 2516-OIK:53", Ankara.

Devlet Planlana Teskilat! (DPT) (2001). Gülij Ekonomi. Ankara.

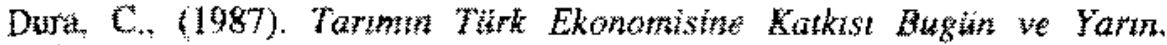
Istanbul,

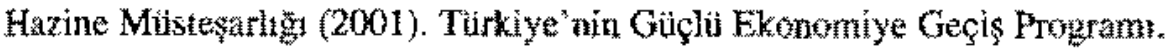
Ankara.

Tanm ve Koy İșer Bakanlı

Tanmi ve Kôy İsleri Bakanlig (2000 b). 2000 İstatistikleri. Ankata,

Tirkiye Cumhuriyeti Merkez Rankass (TCMB) (2000). "Niyet Mektubu-2, 18.12.2000'. Ankata.

Turkiye Cumfuriyeti Markez Bankasi (TCMB) (2001). Yeni Niyet Mektubu. Ankara.

Ticaret Odjalan Borsalar Birligi (TOBB) (1990), Tanmn Turkiye Ekonomisine Katkrsı. Ankarat.

Tunç H. (1900). "AT - Turkiye İlş̧kileri Çaçevesinde Avupa Topluluğu'nun Ortak Tanm Politikass ve Türk Tanms", Doktora Tezi, Istanbul.

Tunç, H. (1998). 'Türkiye "nín A yopa Birligi Gümruk Birligi' ne Gimesinin

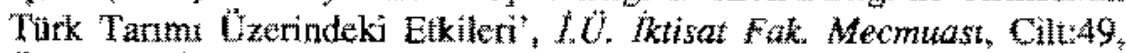
Özel Sayt, Istanbul.

Tunç, H. (2001). 'Finanzal Kriz ve Türkiye Ekonomisi'. ISO Istanbul. 
